ISSN 1678-3921

Journal homepage: www.embrapa.br/pab

For manuscript submission and journal contents, access: www.scielo.br/pab

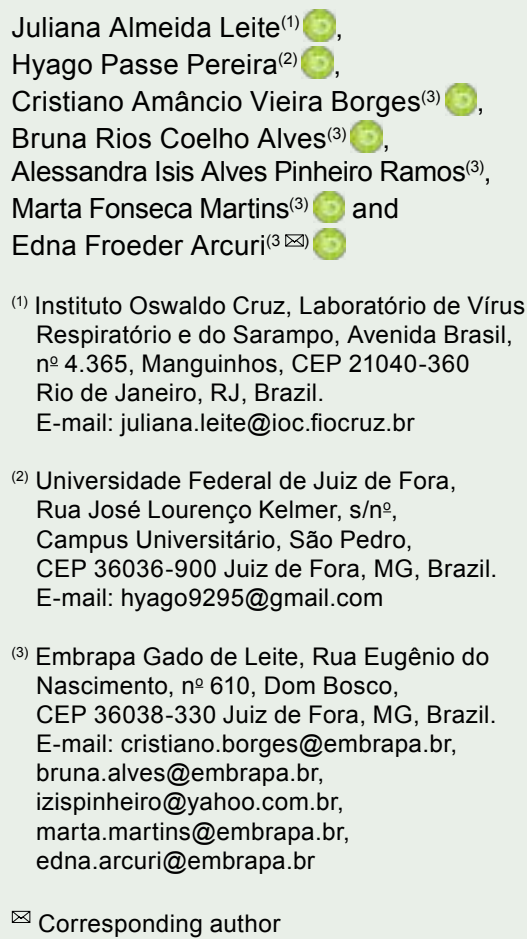

(3) Embrapa Gado de Leite, Rua Eugênio do Nascimento, no 610, Dom Bosco, CEP 36038-330 Juiz de Fora, MG, Brazil. E-mail: cristiano.borges@embrapa.br, bruna.alves@embrapa.br, izispinheiro@yahoo.com.br, marta.martins@embrapa.br, edna.arcuri@embrapa.br

$凶$ Corresponding author

Received

July 9, 2018

Accepted

August 8, 2019

How to cite

LEITE, J.A.; PEREIRA, H.P.; BORGES, C.A.V.; ALVES, B.R.C.; RAMOS, A.I.A.P.; MARTINS, M.F.; ARCURI, E.F. Lytic bacteriophages as a potential alternative to control Staphylococcus aureus. Pesquisa Agropecuária Brasileira v.54, e00917, 2019. DOI: https://doi. org/10.1590/S1678-3921.pab2019.v54.00917.

\section{Lytic bacteriophages as a potential alternative to control Staphylococcus aureus}

\begin{abstract}
The objective of this work was to characterize autochthonous bacteriophages and to determine their lytic activity on Staphylococcus aureus. Six phages were isolated from dairy barn flush water through enrichment cultures with three $S$. aureus strains. All phages were characterized by DNA digestion by restriction enzymes and sequencing of the DNA fragment encoding endolysin. Each phage was tested against $100 \mathrm{~S}$. aureus strains isolated from bovine mastitis and from dairy products using the lysis-plate method. The sequences of the endolysin gene were highly conserved, with nucleotide similarity higher than $99 \%$ among the isolated phages. Three domains involved in the recognition and lysis of the bacterial cell wall were identified. Two bacteriophages isolated from the dairy barns present high lytic activity on $S$. aureus, on a wide range of host strains, indicating their potential for studies on phage therapy in dairy cattle or as a biological control agent for dairy products.
\end{abstract}

Index terms: Staphylococcus aureus, biological control, endolysin, phage.

\section{Bacteriófagos líticos como alternativa potencial para o controle de Staphylococcus aureus}

Resumo - O objetivo deste trabalho foi caracterizar bacteriófagos autóctones e determinar sua atividade lítica em Staphylococcus aureus. Seis fagos foram isolados de água de lavagem de pisos de estábulos por meio do enriquecimento de cultura com três estirpes de $S$. aureus. Todos os fagos foram caracterizados pela digestão do DNA com enzimas de restrição e pelo sequenciamento do fragmento de DNA que codifica a endolisina. Cada fago foi testado contra 100 estirpes de S. aureus isoladas de casos de mastite bovina e de produtos lácteos pelo método de lise em placa. Sequências do gene de endolisina apresentaram alta conservação, com mais de $99 \%$ de similaridade a nível do nucleotídeo entre os fagos isolados. Foram identificados três domínios envolvidos no reconhecimento e na lise da parede celular bacteriana. Dois bacteriófagos isolados de estábulos apresentam alta atividade lítica em S. aureus, em ampla gama de estirpes, o que indica seu potencial para estudos de fagoterapia em gado leiteiro ou como agente de controle biológico para produtos lácteos.

Termos para indexação: Staphylococcus aureus, controle biológico, endolisina, fagos.

\section{Introduction}

Staphylococcus aureus is a gram-positive pathogen responsible for human and animal infections. It is a frequent etiological agent of mastitis, a disease that affects dairy cattle worldwide and causes 
economic losses in the milk production chain (Boldyreva, 2014). Some S. aureus strains, commonly isolated from dairy products, can also produce enterotoxins, which are responsible for staphylococcal food poisoning (Donovan et al., 2006; Obeso et al., 2008; Arcuri et al., 2010). In this context, antimicrobial therapy is an important component of mastitis control in dairy production systems. However, it is dificult to eliminate $S$. aureus from the livestock, since it is moderatly susceptible to antibiotics when the infection is detected at the beginning and hard to cure in chronic infections (Barlow, 2011). Furthermore, a number of studies suggest an increasing antimicrobial resistance in S. aureus (Johler et al., 2011; Wang et al., 2013), complicating staphylococcal disease treatment and highlighting the need to develop novel antimicrobial agents.

Lytic bacteriophages, also known as phages, infect and lyse bacterial cells, resulting in cell death. This was a therapeutic approach developed before the industrial production of antibiotics in the 1940s (Henry \& Debarbieux, 2012). Currently, research on phage therapy is being revived worldwide due to the crisis of bacterial antimicrobial resistance. Different works have reported the efficiency of phages in the control of pathogenic bacteria both in animals (Wang et al., 2017) and foods (Silva et al., 2014).

Lytic $S$. aureus phages have shown effective and comprehensive antimicrobial activity in vitro and in vivo (Donovan et al., 2006; García et al., 2009; Wang et al., 2016; Zhang et al., 2017). These phages are interesting in the context of new methods to control the pathogen since they are natural bactericidal agents, ubiquitous in nature, and may have relative low production costs. Moreover, their genomics can be exploited towards producing endolysins, which target the integrity of the host cell wall and attack specifically one of the four major bonds in the peptidoglycan (Donovan et al., 2006; Fischetti, 2010). Recombinant endolysins have been characterized for use against $S$. aureus in the treatment of bovine mastitis and in bacterial control in milk and derivatives (Obeso et al., 2008; Li \& Zhang, 2014; Fan et al., 2016).

The objective of this work was to characterize autochthonous bacteriophages and to determine their lytic activity on Staphylococcus aureus.

\section{Materials and Methods}

Phages were isolated from 20 samples of barn flush water collected from four dairy herds located in the Zona da Mata region, in the state of Minas Gerais, Brazil (21 $\left.{ }^{\circ} 45^{\prime} 51^{\prime \prime} \mathrm{S}, 43^{\circ} 20^{\prime} 59^{\prime \prime} \mathrm{W}\right)$. The enrichment culture method described by Cerveny et al. (2002), with some modifications, was used for phage isolation. Each sample of barn flush water was clarified by centrifugation at $3,000 \mathrm{~g}$ for $10 \mathrm{~min}$, and supernatants were filtered through $0.45-\mu \mathrm{m}$ pore membranes. A total of $1.0 \mathrm{~mL}$ filtrate was added to $100 \mathrm{~mL}$ Brain Heart Infusion broth (DIFCO, Becton, Dickinson and Company, Franklin Lakes, NJ, USA) with a mixed culture of three $S$. aureus strains used for enrichment, being centrifuged and filtered through $0.22-\mu \mathrm{m}$ pore membranes after incubation for 48 hours at $37^{\circ} \mathrm{C}$. The double-layer method was used for all phage detections, isolations, and purifications, as in Green \& Sambrook (2012), and clear lysis zones were interpreted as a positive result. Serial dilutions were performed to obtain single phage plaques, which were propagated three times by this method to ensure the purity of the phage cultures.

The host range of the isolated phages was determined by the classical spot-test assay, according to Adams (1959). Each phage was tested three times against $100 \mathrm{~S}$. aureus strains -64 from the milk of cows with clinical or subclinical mastitis, 23 from bulk milk cooling tanks, and 13 from "Minas Frescal" cheese -, as well as against Escherichia coli ATCC 25922, Listeria monocytogenes ATCC 19117, and Streptococcus agalactiae ATCC 12386, belonging to the bacteria collection of Embrapa Gado de Leite, located in the municipality of Juiz de Fora, in the state of Minas Gerais, Brazil. Target bacterial lawns were prepared with overnight cultures on Brain Heart Infusion agar (DIFCO, Becton, Dickinson and Company, Franklin Lakes, NJ, USA) plates, and $10 \mu \mathrm{L}$ purified phages $\left(10^{8}\right.$ pfu $\mathrm{mL}^{-1}$ ) were spotted. Plates were incubated at $37^{\circ} \mathrm{C}$, overnight, and the appearance of clear zones around the point of application was considered as the ability to lyse that strain.

The data were analyzed by the Wilson method, used to obtain the confidence interval (CI) for the estimated proportion of strains susceptible to the isolated phages, according to Brown et al. (2001), with the confidence level set to $95 \%$. Analyses were performed in the R

Pesq. agropec. bras., Brasília, v.54, e00917, 2019

DOI: 10.1590/S1678-3921.pab2019.v54.00917 
software, version 3.6.1, using the binconf function of package Hmisc (2019).

Phage DNA was isolated from purified phages by the phenol-chloroform extraction method (Green \& Sambrook, 2012). Briefly, after phage propagation, bacterial debris was pelleted by centrifugation at $9,000 \mathrm{~g}$, for $20 \mathrm{~min}$, at $4^{\circ} \mathrm{C}$, and the supernatant was treated with DNase I and RNase A (Invitrogen, Thermo Fisher Scientific, Carlsbad, CA, USA) to remove any bacterial nucleic acid. The phage pellet was obtained by centrifugation at 25,000 rpm, for 2 hours, at $4^{\circ} \mathrm{C}$, and, then, resuspended in SM buffer; sodium dodecyl sulfate and proteinase $\mathrm{K}$ were added to a final concentration of $0.5 \%$ and $50 \mu \mathrm{g} \mathrm{mL}$, respectively. Following incubation at $65^{\circ} \mathrm{C}$, for $10 \mathrm{~min}$, the solution was deproteinated twice by extraction with an equal volume (25:24:1). DNA was precipitated with sodium acetate and ethanol and then pelleted with a microcentrifuge. After being washed with $70 \%$ ethanol, the DNA pellet was air dried and resuspended in a Tris-EDTA buffer.

Six phages were molecularly characterized by DNA digestion with the restriction enzymes EcoRI, XbaI, XhoI, and HindIII (Invitrogen, Thermo Fisher Scientific, Carlsbad, CA, USA) according to supplier instructions. After digestion, samples were subjected to electrophoresis in $1 \%(\mathrm{w} / \mathrm{v})$ agarose, containing $1 \mu \mathrm{g} \mathrm{mL}^{-1}$ ethidium bromide.

The putative endolysin gene region in phage DNA was amplified by the polymerase chain reaction (PCR) using the primers previously described by Donovan et al. (2006). DNA was amplified by 45 cycles of $95^{\circ} \mathrm{C}$ for $1 \mathrm{~min}, 50^{\circ} \mathrm{C}$ for $1 \mathrm{~min}$, and $72^{\circ} \mathrm{C}$ for $1 \mathrm{~min}$, with a final extension of $72^{\circ} \mathrm{C}$ for $15 \mathrm{~min}$. Amplification was performed in the GeneAmp PCR System 9700 (Applied Biosystems, Thermo Fisher Scientific, Foster City, CA, USA). The reactions were carried out in a $50 \mu \mathrm{L}$ volume consisting of $1 \mathrm{X}$ PCR buffer, $1.5 \mathrm{mmol} \mathrm{L}^{-1} \mathrm{MgCl}_{2}, 10 \mu \mathrm{mol} \mathrm{L}^{-1}$ of each dNTP, 20 pmol of each primer, 100 ng phage DNA, and $3.0 \mathrm{U}$ Taq DNA polymerase (Invitrogen, Thermo Fisher Scientific, Carlsbad, CA, USA). The PCR products were visualized by gel electrophoresis in a $1.2 \%$ agarose gel (w:v), stained with ethidium bromide, and photographed under UV light in the Eagle Eye II imaging system (Stratagene, Agilent Technologies, La Jolla, CA, USA).
Nucleotide amplicon sequencing was performed using the DYEnamic ET Terminator Cycle Sequencing Kit in the MegaBACE 1000 DNA Sequencing System (GE Healthcare Bio-Sciences AB, Uppsala, Sweden). Final sequences were assembled using the CAP3 software (Huang \& Madan, 1999), with all contigs with a depth of coverage of at least three times. Searches for nucleotide and amino acid sequence alignments were carried out with nucleotide sequences and deduced gene products, using BlastN, Blast X, and BlastP (Blast, 2018). For the phylogenetic analysis, the inferred sequences were compared with sequences of other phages on the GenBank, using the MEGA, version 4, software (Tamura et al., 2007). In silico analysis, also involved searches for specific protein domains and conserved motifs with a known function were identified by comparing the endolysin amino acid sequences of the six isolated phages with those of phage phi11 - GenBank accession number AF424781 (GenBank, 2018) -, which were aligned with the DNASTAR software (DNASTAR, 2018).

\section{Results and Discussion}

Six phages, named phage $1,2,3,4,5$, and 6 , were isolated from the samples of barn flush water using three $S$. aureus host strains. All phages formed clear lysis plaques on the bacterial lawns of the $S$. aureus host strains (Figure 1). However, none of the phages were able to form a plaque on E. coli ATCC 25922, $L$. monocytogenes ATCC 19117, and S. agalactiae ATCC 12386.

The purified phages had variable capacity of forming lysis plaques on the $100 \mathrm{~S}$. aureus strain lawns tested (Figure 2). Phages 2 and 4 showed high intensities of lytic activity, evidenced by the high proportions of $S$. aureus strain susceptibility, ranging from 69 to $100 \%$; for the other phages, the proportions were all lower than $47 \%$. There are reports of the successful use of lytic phages to control $S$. aureus in milk products (Garcia et al., 2009; Bueno et al., 2012) and in animal infections (Mishra et al., 2014; Hamza et al., 2016; Zhang et al., 2017). In the present study, phages 2 and 4 show potential to be evaluated as biocontrol agents.

Restriction profiles were similar for all phages when genomic DNA was digested with EcoRI, HindIII, and XhoI. Genomic digestions with the restriction enzyme $X b a$ I revealed similarities among the restriction profiles 
of phages $1,2,3$, and 6 , as well as between phages 4 and 5 (Figure 3). Other authors also found similar restriction profiles among different phages isolated at distinct locations (O'Flaherty et al., 2005; Mishra et al.,

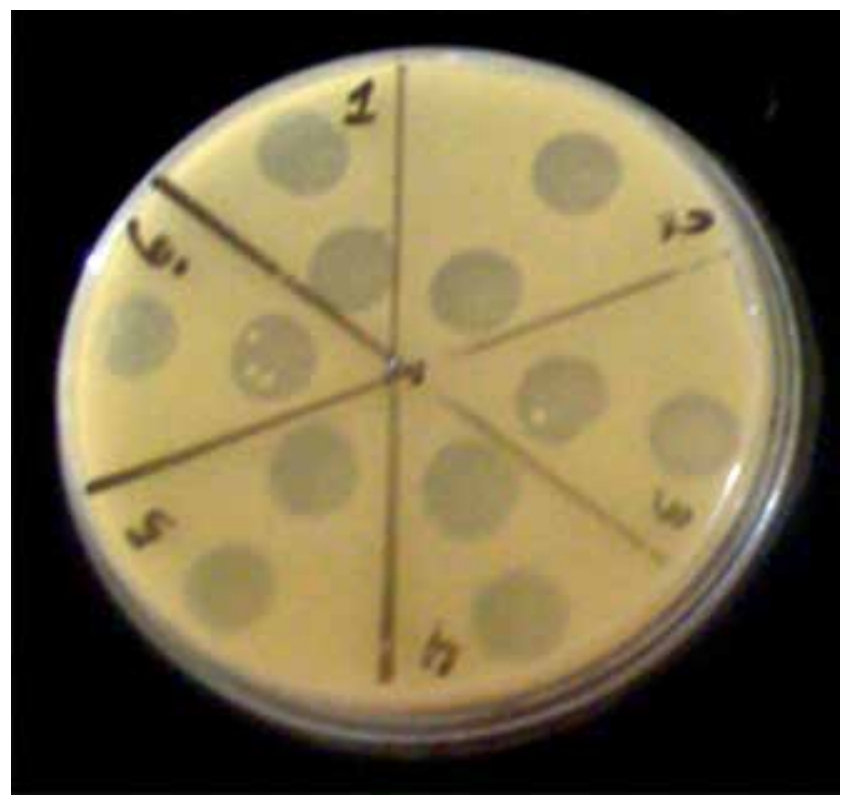

Figure 1. Lytic activity of the isolated bacteriophages against a Staphylococcus aureus strain isolated from a milk sample collected from a milk cooling tank. 1, phage $1 ; 2$, phage $2 ; 3$, phage $3 ; 4$, phage $4 ; 5$, phage 5 ; and 6 , phage 6 .

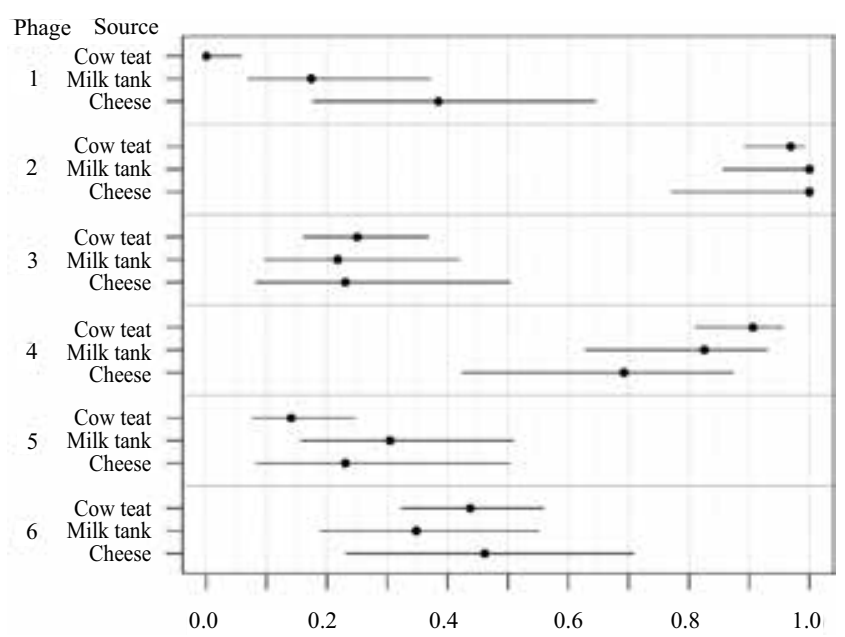

Figure 2. Proportions of Staphylococcus aureus strains isolated from the milk of cows with clinical or subclinical mastitis ( $n=64$ binomial trials for each phage type), from bulk milk cooling tank $(\mathrm{n}=23)$, and from Minas Frescal cheese $(n=13)$, showing susceptibility to the isolated bacteriophages, with a confidence interval of $95 \%$.
2014). Despite the strong genetic relationship among the six evaluated phages, their host range and lytic activities differ, as previously mentioned. Therefore, phages 2 and 4, with wider host ranges, could be the most indicated to control $S$. aureus.

The size of the sequenced amplicons of the endolysin gene was 1,455 base pairs for all six phages. These sequences are available in the GenBank (2018), under accession numbers GU722132, GU722134, GU722133, GU722135, GU722136, and GU722131 for phages $1,2,3,4,5$, and 6 , respectively. The endolysin gene presented a highly conserved sequence, with a nucleotide similarity higher than $99 \%$ among the isolated phages (Table 1). In fact, the nucleotide identity between the endolysin gene sequences of phages 2
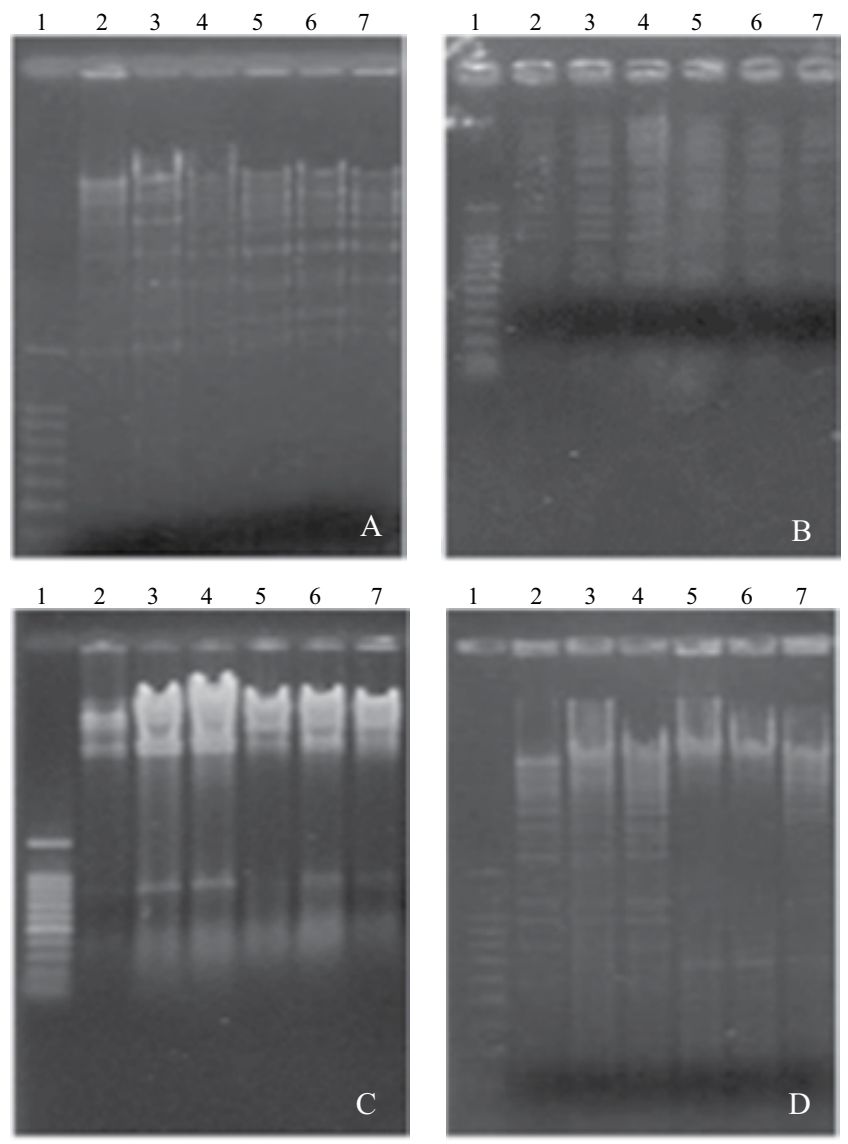

Figure 3. Genomic restriction profiles of the isolated bacteriophages. Viral DNA was extracted and digested with the EcoRI (A), HindIII (B), XhoI (C), and XbaI (D) enzymes. Lanes: 1, molecular weight using the 100bp DNA ladder (Promega Corporation, Madison, WI, USA); 2, phage $1 ; 3$, phage $2 ; 4$, phage $3 ; 5$, phage $4 ; 6$, phage 5 ; and 7 , phage 6 . 
and 4, which showed the highest lytic activity, was $99.99 \%$. However, nucleotide similarity was lower for the sequences obtained for phages $1,3,5$, and 6 . It should be noted that the endolysin gene sequences of the phages with a lower host range and lytic activity also showed higher nucleotide similarity; in this case, phages 1 and 6 had 100\% nucleotide identity. The nucleotide sequence of the endolysin gene of the isolated phages presented an identity lower than $99 \%$ in relation to the other phage sequences available in the GenBank, indicating a closer relationship among the isolated phages. Similar results were found by $\mathrm{Wu}$ et al. (2019) when working with a phage specific to Acinetobacter baumannii.

The phylogenetic analysis of the nucleotide sequences of the endolysin genes showed a clustering of the isolated phages into three groups (Figure 4). Phages 1,5 , and 6 were clustered together, as well as phages
2 and 4; however, phage 3 was placed separately on a different branch. Phages 2 and 4 presented a higher phylogenetic distance in relation to the other phages, correlating to the lytic activity tests (Figure 2). The phylogenetic tree, based on the inferred amino acid sequence of the endolysin gene of the six phages and of the other phages from the GenBank, showed that the phages evaluated in the present study were clustered on the same branch, being related to phage phiMR25 (Figure 5). These phages were clustered on a separate branch of phage phi11, whose endolysin gene was the first one to be characterized, being considered the prototype (Donovan et al., 2006). Inside the isolated phage cluster, phages $1,3,5$, and 6 were grouped in the same subgroup, reinforcing the distance among the endolysin gene of these phages and of phages 2 and 4 in the phylogenetic reconstruction based on nucleotide sequences (Figure 4). This strongly suggests that a few

Table 1. Similarity among the endolysin nucleotide sequences of the six isolated bacteriophages (phages 1 to 6 ) and of the other phages available in the GenBank (2018).

\begin{tabular}{|c|c|c|c|c|c|c|}
\hline \multirow{2}{*}{ Phage } & \multicolumn{6}{|c|}{ Nucleotide identity (\%) } \\
\hline & Phage 1 & Phage 2 & Phage 3 & Phage 4 & Phage 5 & Phage 6 \\
\hline Phage 1 & - & & & & & \\
\hline Phage 2 & $99.5 \%$ & - & & & & \\
\hline Phage 3 & 99.7 & 99.6 & - & & & \\
\hline Phage 4 & 99.5 & 99.9 & 99.6 & - & & \\
\hline Phage 5 & 99.8 & 99.6 & 99.7 & 99.6 & - & \\
\hline Phage 6 & 100 & 99.5 & 99.8 & 99.5 & 99.9 & - \\
\hline phiMR25 & 98.9 & 98.7 & 98.7 & 98.7 & 98.8 & 98.9 \\
\hline 92 & 96.0 & 95.9 & 95.8 & 95.9 & 95.9 & 96.0 \\
\hline 29 & 95.7 & 95.7 & 95.5 & 95.7 & 95.7 & 95.7 \\
\hline 69 & 95.5 & 95.6 & 95.5 & 95.6 & 95.5 & 95.5 \\
\hline phi11 & 95.2 & 95.1 & 95.0 & 95.1 & 95.1 & 95.2 \\
\hline phiMR11 & 95.1 & 95.2 & 95.1 & 95.2 & 95.1 & 95.1 \\
\hline 88 & 94.4 & 94.5 & 94.4 & 94.5 & 94.4 & 94.4 \\
\hline phiNM2 & 94.1 & 94.0 & 93.9 & 94.0 & 94.0 & 94.1 \\
\hline $52 \mathrm{~A}$ & 93.8 & 93.9 & 93.7 & 93.9 & 93.7 & 93.8 \\
\hline 80 & 93.8 & 93.9 & 93.7 & 93.9 & 93.7 & 93.8 \\
\hline 85 & 92.7 & 92.7 & 92.7 & 92.7 & 92.6 & 92.7 \\
\hline 55 & 92.3 & 92.4 & 92.2 & 92.4 & 92.2 & 92.3 \\
\hline phiH5 & 89.2 & 89.3 & 89.2 & 89.3 & 89.1 & 89.2 \\
\hline phiSauS-IPLA88 & 89.2 & 89.3 & 89.3 & 89.3 & 89.1 & 89.2 \\
\hline $\mathrm{X} 2$ & 85.4 & 85.5 & 85.4 & 85.5 & 85.4 & 85.4 \\
\hline 37 & 73.8 & 73.8 & 73.7 & 73.8 & 73.7 & 73.8 \\
\hline EW & 69.5 & 69.5 & 69.4 & 69.5 & 69.5 & 69.5 \\
\hline
\end{tabular}




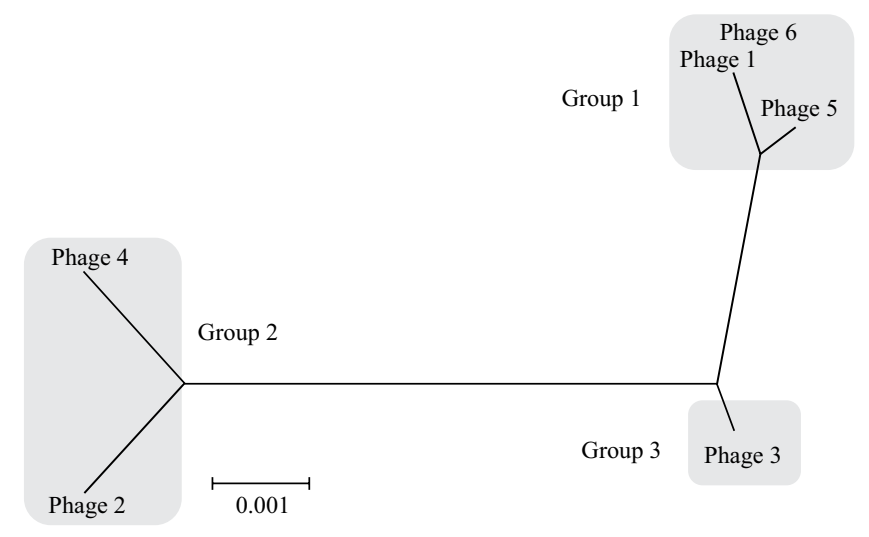

Figure 4. Phylogenetic relationships of the endolysin gene sequences of the isolated bacteriophages. The neighborjoining tree was generated by the MEGA, version 4, software (Tamura et al., 2007). The evolutionary distances are expressed in units of the number of nucleotide substitutions per site (scale bar). The analysis was based on 1,000 bootstrap replicates, with a cutoff value of $95 \%$. nucleotide or amino acid variations may dramatically change host range, as observed by Wu et al. (2019). In this case, phages 2 and 4 could be the most indicated for therapeutic use.

The sequence analysis of the 481 amino acids inferred from the endolysin gene sequence of each isolated phage showed that these phage endolysins are also a modular enzyme. Three distint domains were identified on the endolysin sequences: cysteine; histidinedependent amidohydrolase/peptidase (CHAP); amidase 2 (N-acetylmuramyl-L-alanine amidase); and SH3b, involved in bacterial cell wall recognition according to Son et al. (2018) (Figure 6 A). The endolysins expressed by the isolated phages potentially have domains for recognition and lysis of the $S$. aureus cell wall. Therefore, this modular organization containing three domains has been previously described for other

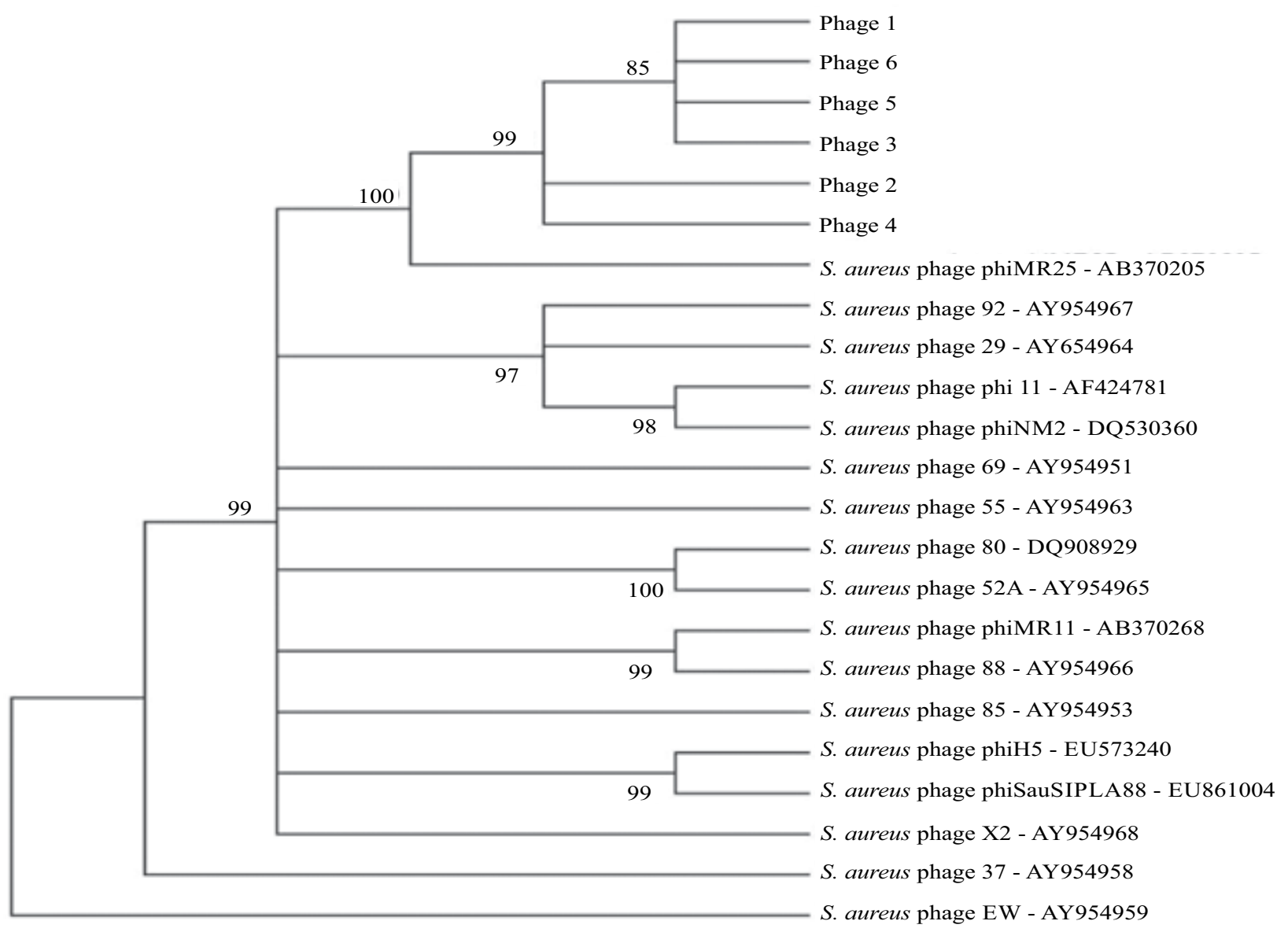

Figure 5. Bacteriophage phylogeny reconstruction based on the amino acid sequence inferred from the endolysin gene nucleotide sequence. GenBank accession numbers are given after dash (GenBank, 2018). The analysis was based on 1,000 bootstrap replicates, with a cutoff value of $95 \%$. 


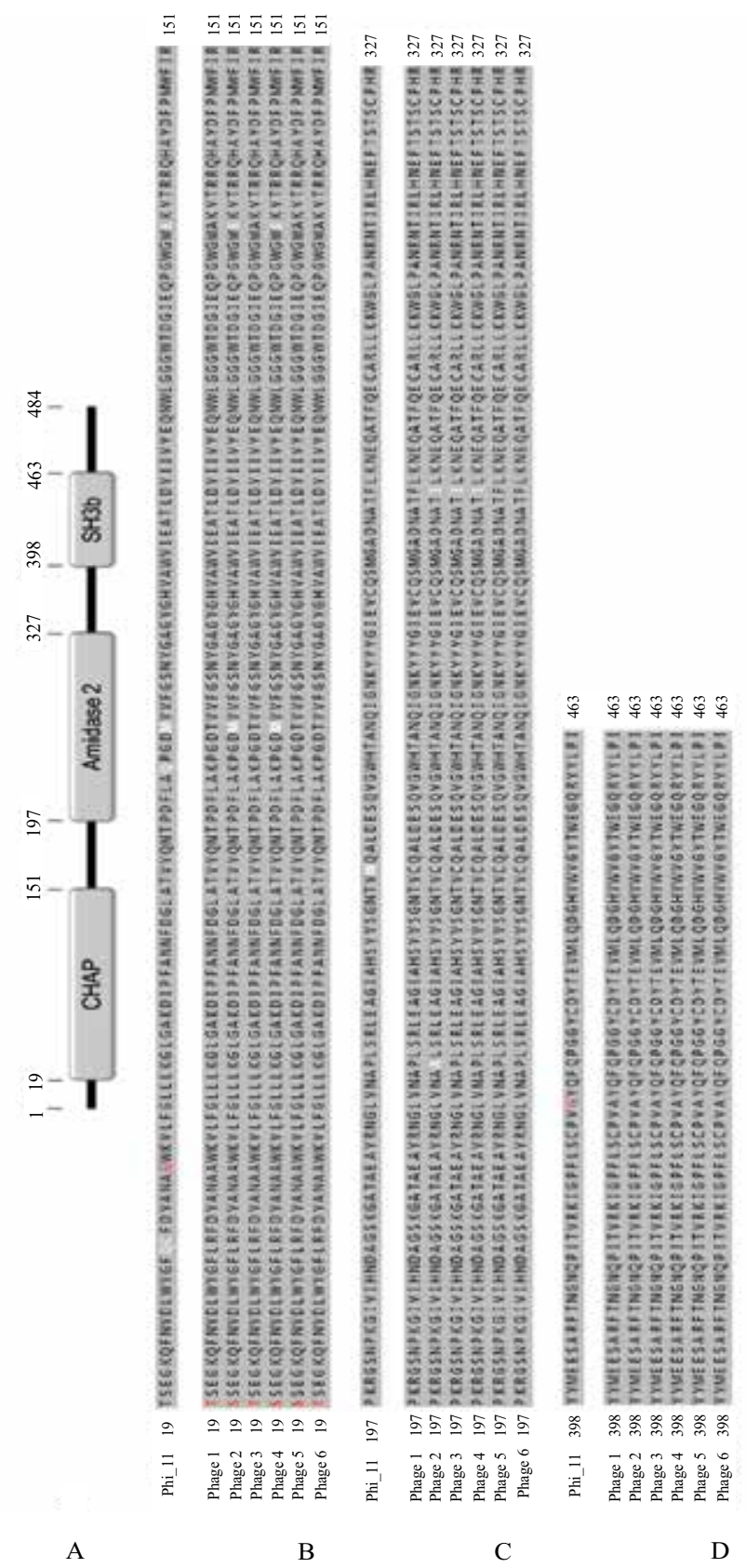

Figure 6. Amino acid sequence analysis of the endolysins of the isolated bacteriophages, showing the cysteine, histidine-dependent amidohydrolase/peptidases (CHAP), $\mathrm{N}$-acetylmuramyl-L-alanine amidase (amidase 2), and $\mathrm{SH} 3 \mathrm{~b}$ (involved in the bacterial cell wall recognition) domains, identified by the Pfam, version 24.0, software (Pfam, 2018) (A); and amino acid sequence alignment of the CHAP (B), amidase 2 (C), and SH3b (D) domains of the isolated lytic phages and phage phi 11, using the DNASTAR software (DNASTAR, 2018). Identical amino acids are shaded in gray, conservative substitutions are marked in red and unrelated amino acids are in white.
S. aureus lytic phages (Donovan et al., 2006; Obeso et al., 2008). Concerning the amino acid sequence of the three domains, phages 1,5 , and 6 presented identical sequences (Figure $6 \mathrm{~B}, \mathrm{C}$ and D), which were similar to that of phage 3 , with only one unrelated substitution in the amidase 2 domain. The amino acid sequence of the three domains of phages 2 and 4 showed a high homology to that of phage phi11, but a lower homology to those of phages $1,3,5$, and 6 . Although the lytic activity of a phage is multifactorial, the high lytic activity presented by the endolysins of phages 2 and 4 could be related to the proximity of the prototype endolysin of phage phi11 (Donovan et al., 2006).

Three domains related to the recognition and lysis of the bacterial cell wall were identified in the present work. Further studies envolving these protein expressions and their potential use as an antimicrobiotic agent should still be conducted.

\section{Conclusions}

1. The host range of the six bacteriophages isolated from Staphylococcus aureus varies.

2. Phages 2 and 4 show a wide host range and potential for $S$. aureus control.

3. The endolysins of the isolated phages are similar to those of previously studied staphylococcal lytic phages.

\section{Acknowledgment}

To Conselho Nacional de Desenvolvimento Científico e Tecnológico (CNPq), for financial support.

\section{References}

ADAMS, M.H. Bacteriophages. New York: Interscience Publishers, 1959. 592p.

ARCURI, E.F.; ÂNGELO, F.F.; GUIMARÃES, M.F.M.; TALON, R.; BORGES, M. de F.; LEROY, S.; LOISEAU, G.; LANGE, C.C.; ANDRADE, N.J. de; MONTET, D. Toxigenic status of Staphylococcus aureus isolated from bovine raw milk and Minas frescal cheese in Brazil. Journal of Food Protection, v.73, p. 22252231, 2010. DOI: https://doi.org/10.4315/0362-028X-73.12.2225.

BARLOW, J. Mastitis therapy and antimicrobial susceptibility: a multispecies review with a focus on antibiotic treatment of mastitis in dairy cattle. Journal of Mammary Gland Biology and Neoplasia, v.16, p.383-407, 2011. DOI: https://doi.org/10.1007/ s10911-011-9235-z. 
BLAST: Basic Local Alignment Search Tool. Available at: $<$ https://blast.ncbi.nlm.nih.gov/Blast.cgi $>$. Accessed on: July 9 2018.

BOLDYREVA, E.M. Current challenges in global dairy farming: cattle diseases. Journal of Dairy, Veterinary \& Animal Research, v.1, p.32-33, 2014. DOI: https://doi.org/10.15406/ jdvar.2014.01.00008.

BROWN, L.D.; CAI, T.T.; DASGUPTA, A. Interval estimation for a binomial proportion. Statistical Science, v.16, p.101-117, 2001. DOI: https://doi.org/10.1214/ss/1009213286.

BUENO, E.; GARCÍA, P.; MARTÍNEZ, B.; RODRÍGUEZ, A. Phage inactivation of Staphylococcus aureus in fresh and hard-type cheeses. International Journal of Food Microbiology, v.158, p.23-27, 2012. DOI: https://doi.org/10.1016/j. ijfoodmicro.2012.06.012.

CERVENY, K.E.; DEPAOLA, A.; DUCKWORTH, D.H.; GULIG, P.A. Phage therapy of local and systemic disease caused by Vibrio vulnificus in iron-dextran-treated mice. Infection and Immunity, v.70, p.6251-6262, 2002. DOI: https://doi.org/10.1128/ IAI.70.11.6251-6262.2002.

DNASTAR. Available at: <https://www.dnastar.com/workflows/ protein/>. Accessed on: July 92018.

DONOVAN, D.M.; MICHELE, L.; FOSTER-FEY, J. Lysis of staphylococcal mastitis pathogens by bacteriophage phil1 endolysin. FEMS Microbiology Letters, v.265, p.133-139, 2006. DOI: https://doi.org/10.1111/j.1574-6968.2006.00483.x.

FAN, J.; ZENG, Z.; MAI, K.; YANG, Y.; FENG, J.; BAI, Y.; SUN, B.; XIE, Q.; TONG, Y.; MA, J. Preliminary treatment of bovine mastitis caused by Staphylococcus aureus, with trxSA1, recombinant endolysin of $S$. aureus bacteriophage IMESA1. Veterinary Microbiology, v.191, p.65-71, 2016. DOI: https://doi.org/10.1016/j.vetmic.2016.06.001.

FISCHETTI, V.A. Bacteriophage endolysins: a novel antiinfective to control Gram-positive pathogens. International Journal of Medical Microbiology, v.300, p.357-362, 2010. DOI: https://doi.org/10.1016/j.jimm.2010.04.002.

GARCÍA, P.; MADERA, C.; MARTÍNEZ, B.; RODRÍGUEZ, A.; SUÁREZ, J.E. Prevalence of bacteriophages infecting Staphylococcus aureus in dairy samples and their potential as biocontrol agents. Journal of Dairy Science, v.92, p.3019-3026, 2009. DOI: https://doi.org/10.3168/jds.2008-1744.

GENBANK. Available at: <http://www.ncbi.nlm.nih.gov/ Genbank $>$. Accessed on: July 92018.

GREEN, M.R.; SAMBROOK, J. Molecular cloning: a laboratory manual. $4^{\text {th }}$ ed. New York: Cold Spring Harbor, 2012. v.1, 2028p.

HAMZA, A.; PERVEEN, S.; ABBAS, Z.; REHMAN, S.U. The lytic SA phage demonstrate bactericidal activity against mastitis causing Staphylococcus aureus. Open Life Sciences, v.11, p.3945, 2016. DOI: https://doi.org/10.1515/biol-2016-0005.

HENRY, M.; DEBARBIEUX, L. Tools from viruses: bacteriophage successes and beyond. Virology, v.434, p.151-161, 2012. DOI: https://doi.org/10.1016/j.virol.2012.09.017.
HMISC: Harrell Miscellaneous. $\mathrm{R}$ package version 4.2-0. Available at: <https://CRAN.R-project.org/package $=$ Hmisc $>$. Accessed on: July 172019.

HUANG, X.; MADAN, A. CAP3: a DNA sequence assembly program. Genome Research, v.9, p.868-877, 1999. DOI: https://doi.org/10.1101/gr.9.9.868.

JOHLER, S.; LAYER, F.; STEPHAN, R. Comparison of virulence and antibiotic resistance genes of food poisoning outbreak isolates of Staphylococcus aureus with isolates obtained from bovine mastitis milk and pig carcasses. Journal of Food Protection, v.74, p.1852-1859, 2011. DOI: https://doi.org/10.4315/0362-028X. JFP-11-192.

LI, L.; ZHANG, Z. Isolation and characterization of a virulent bacteriophage $S P W$ specific for Staphylococcus aureus isolated from bovine mastitis of lactating dairy cattle. Molecular Biology Reports, v.41, p.5829-5838, 2014. DOI: https://doi.org/10.1007/ s11033-014-3457-2.

MISHRA, A.K.; SHARMA, N.; KUMAR, A.; KUMAR, N.; GUNDALLAHALLI BAYYAPPA, M.R.; KUMAR, S.; KUMAR, N. Isolation, characterization and therapeutic potential assessment of bacteriophages virulent to Staphylococcus aureus associated with goat mastitis. Iranian Journal of Veterinary Research, v.15, p.320-325, 2014.

O'FLAHERTY, S.; ROSS, R.P.; FLYNN, J.; MEANEY, W.J.; FITZGERALD, G.F.; COFFEY, A. Isolation and characterization of two anti-staphylococcal bacteriophages specific for pathogenic Staphylococcus aureus associated with bovine infections. Letters in Applied Microbiology, v.41, p.482-486, 2005. DOI: https://doi.org/10.1111/j.1472-765X.2005.01781.x.

OBESO, J.M.; MARTÍNEZ, B.; RODRÍGUEZ, A.; GARCÍA, P. Lytic activity of the recombinant staphylococcal bacteriophage ФH5 endolysin active against Staphylococcus aureus in milk. International Journal of Food Microbiology, v.128, p.212-218, 2008. DOI: https://doi.org/10.1016/j.ijfoodmicro.2008.08.010.

PFAM. Available at: <http://pfam.sanger.ac.uk/>. Accessed on: July 92018.

SILVA, E.N.G.; FIGUEIREDO, A.C.L.; MIRANDA, F.A.; ALMEIDA, R.C. de C. Control of Listeria monocytogenes growth in soft cheeses by bacteriophage P100. Brazilian Journal of Microbiology, v.45, p.11-16, 2014. DOI: https://doi.org/10.1590/ S1517-83822014000100003.

SON, B.; KONG, M.; RYU, S. The auxiliary role of the amidase domain in cell wall binding and exolytic activity of staphylococcal phage endolysins. Viruses, v.10, art.284, 2018. DOI: https://doi.org/10.3390/v10060284.

TAMURA, K.; DUDLEY, J.; NEI, M.; KUMAR, S. MEGA4: Molecular Evolutionary Genetics Analysis (MEGA): software version 4.0. Molecular Biology and Evolution, v.24, p.15961599, 2007. DOI: https://doi.org/10.1093/molbev/msm092.

WANG, S.; WU, C.; SHEN, J.; WU, Y.; WANG, Y. Hypermutable Staphylococcus aureus strains present at high frequency in subclinical bovine mastitis isolates are associated with the development of antibiotic resistance. Veterinary Microbiology, v.165, p.410-415, 2013. DOI: https://doi.org/10.1016/j. vetmic.2013.04.009. 
WANG, Y.; BARTON, M.; ELLIOTT, L.; LI, X.; ABRAHAM, S.; O'DEA, M.; MUNRO, J. Bacteriophage therapy for the control for Vibrio harveyi in greenlip abalone (Haliotis laevigata). Aquaculture, v.473, p.251-258, 2017. DOI: https://doi.org/10.1016/j.aquaculture.2017.01.003.

WANG, Z.; ZHENG, P.; JI, W.; FU, Q.; WANG, H.; YAN, Y.; SUN, J. SLPW: a virulent bacteriophage targeting methicillinresistant Staphylococcus aureus in vitro and in vivo. Frontiers in Microbiology, v.7, art.934, 2016. DOI: https://doi.org/10.3389/ fmicb.2016.00934.
WU, M.; HU, K.; XIE, Y.; LIU, Y.; MU, D.; GUO, H.; ZHANG, Z.; ZHANG, Y.; CHANG, D.; SHI, Y. A novel phage PD-6A3, and its endolysin Ply6A3, with extended lytic activity against Acinetobacter baumannii. Frontiers in Microbiology, v.9, art. 3302, 2019. DOI: https://doi.org/10.3389/fmicb.2018.03302.

ZHANG, L.; SUN, L.; WEI, R.; GAO, Q.; HE, T.; XU, C.; LIU, $\mathrm{X}$; WANG, R. Intracellular Staphylococcus aureus control by virulent bacteriophages within MAC-T bovine mammary epithelial cells. Antimicrobial Agents and Chemotherapy, v.61, e01990-16, 2017. DOI: https://doi.org/10.1128/AAC.01990-16. 